\title{
COVID-19 pandemic and its effect on livestock production: A review
}

Olugbemi, T. S. and Salihu, E. A.

Department of Animal Science,

Faculty of Agriculture,

Ahmadu Bello University, Zaria

*Corresponding author: tsolugbemi@abu.edu.ng; +2348086638349

Abstract

The novel COVID-19 pandemic came with its swindling effect on all sectors of the economy and the livestock sector is not spared. Its impact on livestock production and value chain in Nigeria as in many other countries of the world cannot be overemphasized and can be best understood from the decline in agricultural and other related economic activities, which were brought to almost a total halt during the pandemic. The lockdown policy instituted by various governments affected local and national food production as farmers could not go to their farmlands. Livestock and related products production and prices were impaired. The lockdown also affected the transportation of livestock, livestock products and livestockfeed from farms and industries to the market, and across inter-state borders. COVID-19 threatens many sectors of the economy, resulting in hunger especially in developing countries, reduces animal products' consumption, livestock, livestock farmers and livestock value chain actors suffered a great deal with farmers making less gain resulting from reduced consumption of animal products, and many others lost their jobs from reduced production. There is need for creation of channels for adequate marketing of livestock and products, provision of processing and storage facilities, government, Non Governmental Organizations and individuals should invest in livestock production and research through grants and sponsorships to sustain the industry. Measures should be put in place to facilitate farmer's participation in government regulations on enforcing biosecurity, health standards, disease monitoring, and surveillance practices.

Keywords: Pandemic, Coronavirus, Livestock products, Food security

\section{La pandémie COVID-19 et ses effets sur la production animale - Un bilan}

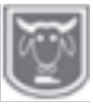

\section{Résumé}

La nouvelle pandémie COVID-19 est venue avec son effet d'escroquerie sur tous les secteurs de l'économie et le secteur de bétail n'est pas épargné. Son impact sur la production animale et la chaîne de valeur au Nigéria comme dans de nombreux autres pays du monde ne peut être surestimé et peut être mieux compris à partir du déclin des activités agricoles et autres activités économiques connexes, qui ont été pratiquement arrêtées pendant la pandémie. La politique de verrouillage instituée par divers gouvernements a affecté la production alimentaire locale et nationale car les agriculteurs ne pouvaient pas accéder à leurs terres agricoles. La production et les prix du bétail et des produits connexes ont été dégradés. Le verrouillage a également affecté le transport du bétail, des produits de l'élevage et des aliments du bétail depuis les fermes et les industries jusqu'au marché, et à travers les frontières interétatiques. Le COVID-19 menace de nombreux secteurs de l'économie, entraînant la faim en particulier dans les pays en développement, réduit la consommation de produits animaux, le bétail, les éleveurs et les acteurs de la chaîne de valeur de l'élevage ont beaucoup souffert, les agriculteurs réalisant moins de gains résultant de la réduction de la 


\section{COVID-19 pandemic and its effect on livestock production: A review}

consommation de produits animaux, et de nombreux autres ont perdu leur emploi en raison de la réduction de la production. Il est nécessaire de créer des canaux pour une commercialisation adéquate du bétail et des produits, la fourniture d'installations de transformation et de stockage, le gouvernement, les organisations non gouvernementales et les particuliers devraient investir dans la production animale et la recherche par le biais de subventions et de parrainages pour soutenir l'industrie. Des mesures devraient être mises en place pour faciliter la participation des agriculteurs à la réglementation gouvernementale sur l'application de la biosécurité, les normes sanitaires, le suivi des maladies et les pratiques de surveillance.

Mots clés: Pandémie, Coronavirus, Produits de bétail, Sécurité alimentaire

\section{Introduction}

Livestock production refers to domesticated animals raised for food and other economic gain and is one of the most widespread human activities, which make it a key contributor to global food security. It has improved dramatically due to improvements in nutrition, animal health, and breeding and genetics (FAO, 2016). Livestock products are estimated to contribute about $30 \%$ of the agricultural gross domestic product (GDP) in Africa (FAO, 2020a) and 3\% in Nigeria to the agricultural GDP (Kamuanga et al., 2008). This contribution of the livestock industry to rural agricultural development forms a basis and an integral drive towards attaining food security, enhancing poverty alleviation and securing national economic stability (FAO, 2020b). The survival of this industry is however threatened by the novel COVID19 pandemic that is ravaging the world and its economy. COVID-19 pandemic which is corona virus disease, 2019, is an infectious disease of humans caused by a newly discovered coronavirus: severe acute respiratory syndrome coronavirus 2 (SARS-CoV-2) (WHO, 2020). The most common symptoms of COVID-19 are fever, tiredness, dry cough and shortness of breath or difficulty in breathing (WHO, 2020; Center for Disease Control and Prevention, 2020). According to available reports (WHO, 2020; Yang et al., 2020; Zhou et al., 2020), some patients may have aches and pains in joints or muscles, repeated shaking with chills, nasal congestion, runny nose, sore throat, diarrhea, and loss of smell and taste in some cases. In severe cases, COVID-19 can be complicated by acute respiratory disease syndrome, sepsis and multiple organ failure (Yang et al., 2020). The SARS-CoV-2 is zoonotic and as such affects humans and some animals (O'Connor et al., 2020; FAO, 2020b) hence, it is not a surprise to find that domestic animals living closely with COVID-19 positive human cases are exposed to the virus, either through environmental contamination, or through human-animal interactions. Positive findings by polymerase chain reaction (PCR) in household animals such as dogs and cats from households of COVID-19 patients have been reported (OIE, 2020; Zhang et al, 2020). This raises concerns about the possibility of humans transmitting the virus to domestic animals, and the potential role that domestic animals could play in the spread of the virus between each other. Reverse zoonotic transmission has been seen in tigers in Bronx Zoo (OIE, 2020) and minks in two farms in The Netherlands (De Rijksoverheid, 2020 ). The interconnectivity of humans, animals and the environment is important in understanding and tackling any threats to food systems, agricultural production and livelihoods. This is particularly important in rural livestock farming communities where animals play an important role for society and food security - providing, income, 


\section{Olugbemi and Salihu}

transport, fuel and clothing as well as food (FAO, 2020b). The rise in the number of confirmed cases and death rate across the globe compelled the World Health Organization (WHO) to declare COVID-19 as a pandemic (Cucinotta and Vanelli, 2020). The increasing rate of these outbreaks might be attributed to the climate change, disruption of ecosystem, land use change for industrial agriculture, deforestation, biodiversity loss, and the removal of essential protective barriers (IPES-Food, 2020). As the search for appropriate medication and vaccine for COVID-19 continues, part of the prevention strategies adopted globally to curb the spread include social distancing (about 2 metres apart), strict personal hygiene, travel bans and vehicle movement restrictions with waiver for livestock feeds and human food items. Achieving a sustainable food production to feed the massive populace has been posing a serious challenge to most developing countries across the globe, particularly in SubSaharan Africa (Sasson, 2012). Unprecedented population surge in recent times far beyond the earlier infinitesimal rate of growth, high prevalence of poverty, double burden of endemic infectious, noncommunicable diseases, and the negative impacts of global warming and climate change on feed-food production chain are among the critical factors responsible for such food insecurity (Tijjani and Ma, 2020). Evidently, challenges which ensued from the current pandemic has outspanned the health sectors, hence, calling for a more helpful approach by all sectors of the economy. Therefore, efforts to highlight its direct and indirect effects on agricultural production, livestock feed industry (feed additives and finished feeds), agro-allied sectors, marketing and distribution outlets, and economies of food production would assist greatly in adequate planning and implementation of policies and programmes to achieve food and nutrition security during and after the pandemic (FAO, 2020a).

\section{Effect of COVID-19 on the economy and agricultural sector}

The virus responsible for the COVID-19 disease, SARS-CoV-2 is zoonotic in origin, as such can infect humans and animals (Peltz, 2020). Farmers have been considered particularly vulnerable to infections due to their proximity to animals and the zoonotic risk associated with the COVID-19 virus (Li et al., 2019). Reported cases of infected pets such as dogs, and cats, have raised concerns regarding transmission between livestock and farmers. Besides, research has postulated that some farm animals including pigs, ducks, and chickens were not susceptible to the SARS-CoV-2 virus; but are carriers of other pathogenic organisms, that may pose a potential threat to humans and can reduce human immunity and pose an imminent risk to human health (Broom, 2020). Although still under investigation, there is a need to further validate these findings under commercial livestock conditions. Alongside this, on-farm disease surveillance, and health care services are either unavailable or inadequate, thus, putting the health and safety of the farmers at risk (Feevre, 2020). The problem of farm and job security also arises following infection of workers and economic disruptions in the livestock value chain, as all stages, from production, processing, marketing, distribution, and consumption have been affected and may lead to layoffs of the workforce, thus creating massive unemployment and loss of income (ElSawalhy, 2020). During pandemics, the livestock sector often accounts for significant economic losses, with implications for food security, especially in regions that are heavily dependent on this sector. With the emergence of COVID-19, the limitations enforced on the animal- 


\section{COVID-19 pandemic and its effect on livestock production: A review}

human interface has resulted in adverse impacts for both livestock production and associated livelihoods. In a bid to curtail the risk of COVID-19 disease transmission, policy responses to limit interhuman contacts and complete shut-down of human activities in severely affected regions have resulted in associated drastic effects on animal production, farm outputs, and supplies to markets (FAO, 2020a). Proper management of farm animals allows for their daily access to feed, water, medication, and other production supplies as necessary. The inability of farmers to freely conduct their rearing activities or possibly have access to farm inputs would culminate in affecting not only the welfare of farm animals, but the farmer's livelihood, and consumer's access to goods and services.

Effect of COVID-19 on livestock sector and value chain

COVID-19 has had a substantial impact on many sectors at global, regional and national levels, including the livestock sector (FAO, 2020b). The actions taken in many countries, such as lockdown, travel restrictions and border controls, have resulted in unintended or negative consequences for the livestock sector. Nomadic herdsmen are particularly affected by movement restriction since their farming activities are heavily reliant on movement across grasslands in search of natural resources. The ease of access to extension services and technical experts to troubleshoot farm problems is hampered especially in rural areas with inadequate access to digital service for ready access to information (FAO, 2020c). Restrictions on movement during efforts to contain the COVID-19 pandemic are affecting the livelihoods of livestock-owning households. For example, through reduced access to animal health care, inputs, markets, and even to pastures and water. There is a high risk that these populations could adopt negative coping mechanisms, like the sale of livestock at much reduced prices, which would have long-term implications for their food security (Calderon et al., 2020). In the short term, poor terms of trade and limited access to markets to sell or buy food items and inputs will potentially aggravate already high levels of severe food insecurity. Poor livestock conditions resulting from less access to veterinary care or sources of feed and forage would also have serious implications on the health and nutrition status of children (Francis and Pegg, 2020). The livelihoods of livestock producers are extremely exposed to the impacts of the pandemic, particularly transhumant pastoralists and women who make up a large portion of backyard livestock (small ruminants, poultry) producers, processors and vendors in informal markets (ElSawalhy, 2020).

Mitigating the impact of COVID-19 on livestock production

Resilient move to curb these impacts include but not limited to:

\section{Livestock and livestock product trade and marketing}

Access to markets and opportunities for continued trade is critical as it is the only means by which livestock owner households, especially pastoralists, obtain income (food diversification, healthcare and education) besides exchanging livestock breeds and types (Actionaid, 2020).

\section{Livestock off take}

This is indeed a time sensitive issue in view of seasonality and market prices. It is also crucial that the cross border trade flows for livestock, products, as well as inputs and services continue unhindered with strict adherence to requisite hygiene, sanitary and phyto-sanitary measures to protect people from COVID-19 as well as livestock from diseases, pests, or contaminants of products. Livestock markets need to operate 


\section{Olugbemi and Salihu}

within measures that reduce the risk of spreading the SARS-CoV-2 virus. The local governments should regulate access and functioning in order to secure the markets in accordance with stipulated guidance of the World Health Organization (WHO) and measures by the government (Zhou et al., 2012).

\section{Access to animal health services}

Access to veterinary treatment and vaccinations at the right time is critical to livestock owners, as they may end up losing valuable animals, their production, or be cut off completely from markets due to outbreaks and spread of notifiable diseases (Feevre, 2020). This may lead to starvation in some pastoral households who are wholly dependent on livestock hence the need for one health approach (Nabarro and Wannous, 2014).

Restriction of movement by pastoralists and their herd, including across borders poses a great risk of animal diseases outbreaks. Disrupting routine movements e.g. from wet to dry season grazing areas during the rains may mean that livestock are held in restricted areas, pest infested areas such as ticks, tsetse fly, mosquitoes etc. It is important that disease surveillance and monitoring of risk factors be enhanced during the COVID-19 crisis in order to minimize the risk and exposure of livestock assets. Seasonality and weather related aspects are important to monitor (FAO, 2020d). The pre-positioning of stocks of vaccines could be important in order to avoid uncontrolled rushes in the logistic chain and the centralization and focus of resources mainly on human health. Collaboration with community based animal health workers (CAHWs) be enhanced as they are the service providers at the local level, ensuring that they are well equipped and linked to local government authorities, technical teams and the nearest agro-vet dealers to maintain flows.

\section{Livestock feed access and supplies}

Access to grazing areas as well as feed supplies may be affected by movement restrictions and delays along the supply chain. Pastoralist patterns of migration will be disrupted by border closures as well as internal human movement controls. It is therefore important to ensure continued dialogue between pastoralists and government authorities in order to identify suitable movement options. This will also help in ensuring that livestock access the appropriate feed and natural resources as well as mitigating conflict, including farmers-herders conflict. The COVID-19 restrictions are hampering the normal transhumant movements across states and the access to the humanitarian aids (particularly feed provision). Advocacy is needed not only to minimize the limitations of the transhumance as the only adaptive mechanism to the climatic variability and environmental shock in the Sahel belt but also to open humanitarian corridors with due consideration to COVID-19 hygienic measures (Francis and Pegg, 2020). The provision of livestock feed to small holders or pastoralists whose herds (lactating and pregnant) are left at home due to drought or strained supply chains. In East Africa for example, there are recorded feed shortfalls due to desert locust, in addition to COVID19, these households will be further strained (FAO, 2020d, Cullen, 2020). Cash or voucher interventions alongside the feed are important to ease pressure on the vulnerable households and to enable them obtain other supplementary feed inputs including vitamins, especially for pregnant and lactating herds. The registration for cash plus programming needs to be undertaken with care and due consideration to all measures against the spread of COVID-19. Awareness creation and information of the public e.g. through radio together with the governments including at local levels should be considered (FAO, 2020d). 


\section{COVID-19 pandemic and its effect on livestock production: A review}

\section{Provision and access to water}

Movement needs to be facilitated to allow access to critical watering resources. If there is severe scarcity of water, provision for lactating and breeding herds should be considered with due adherence to WHO regulations. Livestock shelter and settlement, provision of shelter is critical especially in extreme weather events to minimize loss of livestock especially kids, calves and lactating animals. This intervention may need consideration where other hazards, such as, flood, heat wave, earthquake, co-exist with the COVID-19 pandemic (FAO, 2020b).

\section{Provision of livestock in the recovery phase}

The provision of livestock to vulnerable households who are capable of taking good care of them is important (Calderon, 2020). This activity is potentially of great value among internally displaced people (IDPs) as part of measures to decongest IDP camps; facilitating their return home or to settlement areas if they are safe. In South Sudan, for example, there is an opportunity to provide livestock as part of the return package to IDPS, especially those in the protection of civilians' sites which are at high risk of spread of COVID-19. Cash plus interventions to support these previously livestock dependent households is important during the transition period. Provision of livestock is helpful post COVID-19 in supporting households that would have lost their livestock assets (FAO, 2020c).

\section{Coordination and advocacy}

Actors across the livestock value chain can play a critical role in passing along messages related to COVID-19, including on health and safety measures and the reasons for closures and movement restrictions to prevent the spread of the virus. These actors will also be important in countering rumours and false information about the virus, its spread and potential treatment (LEGS, 2014). Key messages on COVID-19 and livestock-related issues should be articulated, agreed upon and widely disseminated at the local level to counter misinformation. Incidences have for example, been recorded in some countries of considerable drops in the sale of livestock products as people fear they could be a source of virus transmission (FAO, 2020a). Thus, messages must clearly explain how the disease is transmitted, as well as how to safely purchase, cook and consume livestock products. Direct sales to restaurants, hotels, and food service vendors have also suffered major setbacks due to low patronage. Following the limitations in airfreights and cargo deliveries of imported goods into the countries, market activities are lulled. The heavy dependence of the livestock sector for imported feed ingredients, medication, and technical experts poses significant constraints on livestock production in African countries. A substantial decline in food imports, between 13 to 25 percent, has been reported in African countries as a result of higher transaction costs and decreased domestic demand (Calderon, 2020).

\section{Conclusion}

There still exists a wide gap in information dissemination and the wrongly held belief of the COVID-19 disease as a "speculation" by several rural households in Africa. This bridge can only be exterminated with proper awareness, and sensitization on COVID-19 safety measures for individuals involved in animal production, handling, processing, marketing, and distribution. As the surge of COVID-19 increases and threatens many sectors of the economy, there is possibility of hunger especially in developing countries of the world, hence, animal products' consumption is reduced as an average individual just eat to survive without considering the nutritional 


\section{Olugbemi and Salihu}

requirement of the body for normal body function. Livestock, livestock farmers and livestock value chain actors suffer a great deal due to restrictions on the movement of personnel, availability of feed ingredients, drugs, and vaccines which are very vital in animal production. Therefore, farmers make less gain resulting from reduced consumption of animal products, and many others loss their jobs from reduced production.

\section{Recommendations}

It is recommended that adequate marketing of livestock and products, adequate processing and storage facilities should be made available with good innovations to mitigate animal product wastage and ensure availability during scarcity. Government, Non Governmental Organizations, organizations and individuals should encourage livestock production by providing sustainable training and supports to farmers through grants, training workshops and access to productive information; and to livestock research institutes by providing research grants and sponsorships to advance their effort towards developing productive management, feeding and health principles to sustain the industry. Prioritizing investment in smallscale farmers and strengthening animal processing and storage facilities would further strengthen access to food as a response against food insecurity. Measures to facilitate farmer's participation in enforcing biosecurity and health standards, disease monitoring and surveillance practices are imminent. In tackling the current COVID-19 pandemic and in preparedness for future disease epidemics, the FAO recommends a "One Health approach", which can holistically address the health of an animal, human and environmental in concert, to achieve the best results (FAO, 2020b).

\section{References}

Actionaid 2020. Right to food, farmers' rights and Covid-19: policy priorities and a call to action. [ A v a i l a b l e fro m : https://actionaid.n l/wpcontent/uploads/2020/06/Right-tofood-and-farmers-rights-andCOVID-19-ActionAid-PolicyBrief.pdf].

Broom, F. 2020. Don't panic, experts say after COVID-19 animal killings. Sci Dev Net 2020 [Cited 2020 Apr 17. Available from: https://www.scidev.net/global/cor onavirus/news/covid-19 -animalkillings.html $\square$

Calderon, C., Kambou, G., Zebaze, D. C., Korman, V., Kubota, M. and Cantu-Canales C. 2020. Africa's pulse: assessing the economic impact of Covid-19 and policy responses in Sub-Saharan Africa; 2020 [Available from: https://s3e u - w e s t 1.amazonaws.com/s3.sourceafrica .net/ documents/119870/Africa-sPulse-Assessing-the-EconomicImpact-of.pdf].

Cucinotta, D and Vanelli, M. 2020. WHO declares COVID-19 a pandemic. Acturial Biomedica, 91: 157-160.

Cullen, M. T. 2020. Coronavirus food supply chain understrain what to do $\square \quad[$ Available from: http://www.fao.org/3/ca8308en/ca 8308en.pdf].

Ejeromedoghene, O., Tesi, J. N., Uyanga, V. A., Adebayo, A. O., Nwosisib, M. C., Tesi, G. O. and Akinyeye, R. O. 2020. Food security and safety concerns in animal production and public health issues in Africa: A perspective of COVID19 pandemic era. Ethics, Medicine and Public Health, 15: 1-8.

El-Sawalhy, A. 2020. Effects on animal 
COVID-19 pandemic and its effect on livestock production: A review

feed availability, veterinary and veterinary public health services, other production inputs and market access. African Union - InterAfrican Animal Resources; 2020.

FAO. 2016 . Livestock-related interventions during emergencies The how-to-do-it manual. Edited by Philippe Ankers, Suzan Bishop, Simon Mack and Klaas Dietze. FAO Animal Production and Health Manual No. 18. Rome.

FAO. 2020a. Guidelines to mitigate the impact of the COVID- 19 pandemic on livestock production and animal health. Rome; 2020 [Available from: http://www.fao. org/3/ca9177en/CA9177EN.pdf].

FAO. 2020b. Mitigating the impacts of COVID-19 on the livestock sector. R 0 m e . https://doi.org/10.4060/ca8799en

FAO. 2020c. Coronavirus disease 2019 (COVID-19) Address-ing the impacts of COVID-19 in food crises April-December 2020; 2020 [Available from: http://www.fao.org/3/ca8497en/ca 8497en.pdf].

FAO. 2020d. Animal agriculture in Africa: opportunities for growth. Food and Agriculture Organization of the United States. [Cited 2020 Jul 3. A v a i 1 a ble f r o m : http://www.fao.org/ag/againfo/ho me/en/news archive/2011 Animal Agriculture in Africa.html

Feevre E. 2020. Domestic livestock not a source of the COVID-19 disease. ILRI; 2020 [Cited 2020 Apr 17. A v a i l a b l e f r o m : https://www.ilri.org/news/domesti c-livestock-not-source-covid-19disease-ilri-veterinaryepidemiologist-eric-fevre].

Francis, N. N. and Pegg, S. 2020. Socially distanced school-based nutrition program feeding under COVID 19 in the rural Niger Delta. Extraction I n d u s t r i a $1 \mathrm{~S}$ o c i e t y, http://dx.doi.org/10.1016/j.exis. 20 20.04.007.

IPES-Food. 2020. COVID-19 and the crisis in food systems: Symptoms, causes, and potential solutions. Communique by the International Panel of Experts on Sustainable Food Systems. Pp. 1-11.

Kamuanga, M. J. B., Somda, J., Sanon, Y. and Kagoné, H. 2008. Livestock and regional market in the Sahel and West Africa: potentials and $\mathrm{c} \mathrm{h}$ a $11 \mathrm{e} \mathrm{ng} \mathrm{e} \mathrm{s.} \mathrm{S} \mathrm{W} \mathrm{A} \mathrm{C} \mathrm{-}$ OECD/ECOWAS; p. $1-170$ [ A v a i l a b l e f r o m : h t t p s: / / w w w.o e c d.org / swac/publications/41848366.pdf].

LEGS. 2014. Livestock Emergency Guidelines and Standards, 2nd edition.

Li, H., Mendelsohn, E., Zong, C., Zhang, W., Hagan, E. and Wang, N. 2019. Human-animal interactions and bat coronavirus spillover potential among rural residents in Southern China. Biosafety and Health; 19 $\left(\begin{array}{l}1 \\ \text { ) : }\end{array}\right.$ http://dx.doi.org/10.1016/j.bsheal. 2019.10.004.

Nabarro, D. and Wannous, C. 2014. The potential contribution of livestock to food and nutrition security: the application of the One Health approach in livestock policy and practice. Revised Science and Technology; 33:475-485.

Peltz, J. 2020. Tiger at NYC's bronx zoo tests positive for coronavirus. Bloomberg; [Cited 2020 Apr 6. $\mathrm{A} v$ a i l a b l e fro m : https://www.bloomberg.com/news /articles/2020-04-05/ tiger-at-nycs-bronx-zoo-tests-positive-forcoronavirus]. 


\section{Olugbemi and Salihu}

Sasson, A. 2012. Food security for Africa: an urgent global challenge. Agriculture and Food Security, 1:2. https://doi.org/10.1186/20487010-1-2.

Tijjani, S. J. and Ma, L. 2020. Is Nigeria prepared and ready to respond to the COVID-19 pandemic in its conflict affected northeastern states $\square$ International Journal for Equity in Health, 19:77. https://doi.org/10.1186/s12939020-01192-6.
Zhou, G., Zhang, W. and Xu, X. 2012. China's meat industry revolution: challenges and opportunities for the future. Meat science; 92 (3): 188-196.

Received: $12^{\text {th }}$ December, 2020 Accepted: $4^{\text {th }}$ March, 2021 